\title{
Developing Video Media learning to Enhance Learning Outcomes of the Learning Media Production Process at Postgraduate Students of Education Technology
}

\author{
Andri Kurniawan, Yatim Rianto \\ Universitas Negeri Surabaya \\ Surabaya, Indonesia \\ andri.kurniawan4@gmail.com
}

\begin{abstract}
This research aimed to develop learning devices which can facilitate and give an explanation to students regarding the production process at educational technology of postgraduate program at Adi Buana University, Surabaya. In fact, not all students had a basic knowledge of learning video development required to produce a single video media learning at the end of a lecture.This learning video development process used the design model ADDIE (Analyze, Design, Development, Implementation and Evaluation). Video learning developed was validated by material and media experts to determine feasibly or in the process of teaching and learning in the classroom. Based on the results of the development of research data, it can be drawn the conclusion that learning video materials are worthy and able to overcome the problem of practicality and ease learning in the classroom and can effectively enhance student learning outcomes.
\end{abstract}

Keywords-development, media production, video learning, learning outcomes

\section{INTRODUCTION}

A lecture is required to equip themselves with a wide range of knowledge, skills as well as being able to choose a good learning and media appropriately. Because the selection of inappropriate learning media will result in lack of liveliness that will result in poor results of student learning.

Educational Technology Postgraduate Programs University PGRI Adi Buana Surabaya there are Courses in Media and Production which is the icon of the Postgraduate Program. Media courses and mandatory Media Production reached by the student in the semester 3 and have the goal of learning that students are expected to do the planning, configuration and the production of a video media of instruction. As a result of the end of the lecture the students obliged to produce video learning.

This subject foster expertise in the field of media development for learning ranging from simple understanding, types, functions, classification, and simple media position, until a simple media production. Its activity is directed at five simple media types currently available graphical, visual media, namely, audio, audio-visual and computer media. The lecture concludes with an evaluation of the activities of the media developed by students. Final assessment of the subjects of Media and the Production based on the aspect of cognitive, affective and psychomotor.

Lectures and Media Production by students traveled with a load of 3 credits for one semester with the composition of $40 \% 60 \%$ theory and practice. On theoretic aspects will be discussed about the characteristics, benefits, techniques the use of audio and video media for learning and development strategy. On the practice of the production will be performed a program of learning appropriate standard operational procedures.

In the aspect of terrific students obtain references concerning the production process of reference books only lectures and handouts while aspects of practice students obtain literature from some video from the production class before.

The steps in producing a video media require a long process and require a foundation of theory and practice while the given time only 1 semester. [1] The other thing that becomes a problem is a student of the course educational technology graduate programs University PGRI Adi Buana Surabaya $80 \%$ is the teacher and not the people who cultivate the field of video. This makes the Media and production are considered a heavy subject for students.

Addressing the above issues, viewed the need to design and develop the learning media can help students understand the process of media production video. [2] stated that the audio-visual media is media that is touching in its use both senses sight or hearing senses simultaneously. Video learning is learning materials which combine two materials, namely visual material and material audit. The material is intended to stimulate audit if senses of hearing, while the visual materials to stimulate the sense of sight. With a combination of two of this material, can create a higher quality learning, because communication takes place more effectively.

If the students only receive explanation material, very possible audition material will be poorly understood. Different case if the explanation through sound is also combined with the picture, then students will further increase the ability to remember it.

Silberman in [3] reveals a research results that by adding a visual on lessons, can raise memories of the $14 \%$ to $38 \%$. The study also shows that there is an improvement of up to $200 \%$ when the vocabulary taught by using a visual tool. In fact, the 
time it takes to convey the concept of reduced up to $40 \%$ when used to add visual-verbal, presentation.

Based on the description of the problem, then the researcher doing product development learning materials in the form of video tutorials learning specially designed (by designed) that could address the problem of students ' learning difficulties thus achieved good theory (concept) or skills in practice.

Formulation of the problem in this research was measuring the feasibility of video learning developed and whether the video learning developed to increase student learning outcomes.

\section{METHOD}

This research is the development of research aimed at developing media video learning. Developers video learning use ADDIE model. According to [4] ADDIE is the concept of product development. Create a product using the process of ADDIE remains one of the most effective. ADDIE is a process that serves as a guiding framework for complex situations, ADDIE is apt to develop education and other learning resources

[5] ADDIE Development model includes (1) Analysis, (2) Design (3) Development), (4) Implementation, and (5) Evaluation. In accordance with the model chosen, analyses conducted includes: students, material production process media video learning. Designs includes: students, objectives, methods, and evaluation. The development is carried out by developing products in the form of video media of instruction. Implementation of validation experts and trial video media of instruction in educational technology postgraduate programs University PGRI Adi Buana Surabaya. A formative evaluation was conducted on the stages of product development and summative stages measure the success of the media addressing learning problems

The fifth stage of the ADDIE procedure can be seen in the chart on the following development stage

1) stage of analyzing researchers create the framework concept of video media learning developed, identifying learning video in accordance with the target learners, learning objectives, identifying the content/learning material, identify the learning environment and delivery strategies in learning. Identify and analyze the data based on the RPS (Learning Plan Semesters) Subjects of Media and Production which contains the subjects Media and standard Production and Production mechanism of Subject Learning Media. The results of the analysis are the initial drafting of a concept for the development of instructional video.

2) The stage Design curriculum review process is done, video learning concept design into the script and storyboards so that it will look how the media is intangible. The result of the development of the concept of the draft manuscript consisting of the design of the video learning developed in the first stage consists of: video consists of five sequence and the user manual contains a guide to the use of video learning and learning video material summary

3) The third stage is development activities which include the activities change material/material into a media video learning. This learning video media into a Prototype then later developed an instrument to measure learning video that includes test media expert, expert content, test a small group and large group testing.

4) The fourth phase activities is the implementation. After obtaining the results from the development of instructional video that is already so Abakan will be tested in the process of learning in technology education course students [6]. A test done 2 times. The first meeting of students were given reserved pre-test, the second meeting students were given material by using video learning and then conducted post-test

5) the last Stage is conducting an evaluation. Evaluation is used to look at the impact of the use of the product, in addition to measure accomplishment product development goals. Evaluation here consists in two phases, namely the formative evaluation and a summative evaluation. A formative evaluation is conducted at each stage of the ADDIE process at a time when the development phase the device learning and testing experts. Summative evaluation while at large group conducted trials

There are two data analysis techniques used to process data from the results of reviews of the experts as well as from individual trials, trials, small group and large group testing, namely by using a descriptive qualitative analysis and analysis descriptive statistics

Qualitative descriptive analysis is used to process data from the review experts and data from trials in students. This data analysis techniques used by grouping informationinformation from the qualitative data in the form of feedback, criticism, or suggestion of improvement on the question form. Data analysis made reference to correct or revise this learning video development products.

The selection of this scale is based on the measuring in excess of one dimension from a multidimensional variable [7] The results of the now will be giving a presentation of an idea of the attitude of the media expert and expert material against video learning whether or not revision will be made

After learning video ready to use performance assessment tools also developed students and assessment of the results of the product. Performance assessment is used as a measure of the impact of video learning media development against aspects of psychomotor students in responding to the video material. The assessment results are used to measure the value of the final product as a result of student learning to the end at the end of the lecture.

\section{RESULTS AND DISCUSSION}

We can see the end result of the analysis of data from learning video development through several revisions of the 
experts, test the eligibility of individuals and small groups and large groups

It is based trial design measures that began with a review by experts of the content or materials. On the results of the review of expert product development learning video material, the depth of the material already exists in media video learning. For the next steps in the review of the learning media expert looks at the results of the review requires a revision on the audio clarity of the narrator, where the narrator's voice still sounds less well. After the revision is done then the media video learning developed already qualified for the next stage tested on.

[8]From individual trial results in educational technology Postgraduate Courses UNIPA showed that overall the quality of the video media learning courses has an average of $92 \%$. This shows that the product video media it is qualification "very high", qualifying this shows that the product media video learning does not require revision again. Trial results data for small groups on the course educational technology Postgraduate UNIPA noted that the average percentage of overall regarding the feasibility of video media learning courses was $86 \%$, this indicates that the product video learning media are at "high" qualification, for this qualification also clarified that the video pembelajaraan media product requires no revision.

Data from tests of a large group noted that the average percentage of the question form given to 28 students Graduate educational technology as UNIPA respondents about how the quality of these learning media video the whole is $79 \%$. This indicates that qualifying media video learning qualifications are at "high" so no need for revision.

From the results of research that has been done, to see that this learning video media has been tested in improving student learning outcomes. The research data obtained using test pretest and post-test. Test the effectiveness of media shows the result of the difference in the results of the post-test score better than pre-test score 8.22 Researchers also developed an instrument to measure students ' performance on the field as an application of the material medium of video. Student performance is measured as the assessment of aspects of psychomotor learning the effectiveness of video media will be developed. The result is the student able to undertake activities in accordance with the production of video material to teach with the acquisition of $86.77 \%$ results. [9] In addition to student test results data and observational instruments performance, researchers also measured the feasibility of video that students develop as the end of the lecture and Media production. Product appraisal question form of students are able to develop the media with good results with the results of $86.77 \%$.

\section{CONCLUSION}

\section{A. Conclusions}

[10] Media video production learning on subjects and Media Production courses which had been developed can improve Student Learning outcomes in educational technology of postgraduate program of Adi Buana University, Surabaya.

\section{B. Suggestions}

This video learning media is the media products which are developed to help the lecturers who provide learning, but given the media learning is already equipped with the Narrator then this learning media video products can also be used for students as a teaching material for independent study.

\section{References}

[1] Y. Miarso, Menyemai benih teknologi pendidikan. Kencana, 2004.

[2] H. Prasetyorini and B. S. Bachri, "Pengembangan Materi Pada Mata Pelajaran IPA Dalam Platform Course Networking Sebagai Media Pembelajaran Secara Blended Learning Untuk Meningkatkan Hasil Belajar Dan Keterampilan Kolaborasi Peserta Didik Kelas VII SMP,” J. Pendidik. (Teori dan Prakt., vol. 1, no. 1, pp. 50-58, 2016.

[3] A. Prastowo, "Metode penelitian kualitatif dalam perspektif rancangan penelitian," Yogyakarta: Ar-Ruzz Media, 2012.

[4] R. M. Branch, Instructional design: The ADDIE approach, vol. 722. Springer Science \& Business Media, 2009.

[5] L. Cheung, "Using the ADDIE model of instructional design to teach chest radiograph interpretation," J. Biomed. Educ., vol. 2016, 2016.

[6] B. B. Seels and R. C. Richey, Instructional technology: The definition and domains of the field. IAP, 2012.

[7] Riduwan, "Belajar Mudah Penelitian untuk Guru-Karyawan dan Peneliti Pemula," Bandung Alf., p. 97, 2007.

[8] J. Warsihna, "Modul Pelatihan Pengembangan Dan Pemanfaatan Konten Jardiknas Pembuatan Media Video," Dep. Pendidik. Nas. Pus. Teknol. Inf. dan Komun. Pendidik., 2009.

[9] D. S. Subroto, "Produksi Acara Televisi," Yogyakarta. Duta Wacana, 1994.

[10] W. J. K. Davies, Learning resources?: an argument for schools, vol. 1. Council for Educational Technology for the United Kingdom: Distributed by Councils and Education Press, 1975. 